\title{
Administrative Problems of Reference and Research Libraries
}

\author{
$M r$. Rogers is librarian, The Grosvenor \\ Library, Buffalo.
}

W HEN I WAS invited to speak at this meeting, it was suggested that my topic be "Administrative Problems of Reference Service." I replied with the alternate suggestion that the topic be "Administrative Problems of Reference and Research Libraries." Except for a certain breadth of approach, these two subjects are not as divergent as they might at first appear because analysis of the big problems of reference service indicates that they are directly related to the big problems of reference and research libraries. Without disparaging the importance of routines, I take the position that we have already entered such a critical period in research library administration that either we shall meet the fundamental issues facing us, or routines will not matter.

I wish to express my appreciation to the dozen or more directors of research libraries who responded to my request for a current appraisal of their problems. Largely through their help, I am prepared to define our problems and to suggest some solutions and new perspectives.

\section{Greatest Problems}

What do we consider our greatest problems? First, there is lack of space, together with inefficient arrangement of collections dictated by buildings which we

1 Paper presented at the meeting of the Reference Librarians Section, A.C.R.L., Jan. 2r, 1949, Chicago. have outgrown or which have been expanded, not with reference to "efficiency but to the emergency need for room. Second, we realize that the card catalog is costing us more and more and that, as subject approach to materials, it is becoming less and less satisfactory. Third, we continue to recognize that reference librarians are not being properly or adequately educated and our criticism is spreading to other members of the staff, particularly to catalogers. Fourth, we realize that there are startling gaps in our collective acquisition of foreign and domestic publications, despite historical assumptions to the contrary, and that we probably should be doing something about the tremendous publishing output in the world today. Finally, we are constantly aware of financial obstacles to the attainment of our objectives.

During the last 20 to 30 years we have dealt with many of these same old problems and have tried, pretty much in vacuo, a number of solutions. What we must now realize is that most of our problems and their solutions are inextricably interwoven and that we must approach them as a group, not individually.

Whether we subscribe to the Farmington idea or concede that there is some truth in Fremont Rider's concept of research library growth, we know our job is going to become increasingly difficult. Let us admit at the outset that we do not know the degree of difficulty because we have no accurate statistics in regard to the past, present or probable future volume of 
published works of all kinds. ${ }^{2}$ We know that from a national standpoint we are woefully weak in many subjects, for example, near eastern and Asiatic materials. Our holdings of world book production to date are estimated to be as low as 33 per cent and as high as 66 per cent. The Library of Congress, which is traditionally the most complete in Americana, is 88 per cent incomplete in some aspects of it. ${ }^{3}$ By such haphazardly statistical or completely unstatistical methods, it has become apparent that the job which lies ahead is going to be infinitely more difficult than imagined.

Let us now consider in some detail the means with which we have been experimenting to solve our problems. Almost every solution has involved some degree of cooperation. Cooperation is such a good American tradition that any plan which involves it has been, prima facie, a step in the right direction and anything done in its name has not been challenged. It is now becoming increasingly clear that we need to temper our enthusiasin for cooperation with some fundamental changes in methodology, and it is with this in mind that I approach past and present solutions.

First, we have the Farmington Plan based on the thesis that research libraries should join in collecting at least one copy of every printed book and pamphlet (and later public document, serial and newspaper) published anywhere in the world; that such material should be promptly cataloged, preferably centrally, and listed in the Union Catalog at the Library of Congress; and that participating libraries should share the expense and should specialize in certain subject fields for which they will assume complete responsibility. ${ }^{4}$ It is too soon to say how practicable this plan will

\footnotetext{
2 Evans, Luther H. "History and the Problem of Bibliography." College and Research Libraries 7:195205, July 1946.

'Evans, Luther H. "National Library Resources." Library Journal 72:7-13, Jan. 1, 1947.

4 Metcalf, Keyes D. and Williams, Edwin E. "Pro-
}

be, how much it will ultimately cost or what the volume of material will be. It might prove too expensive-too huge to handle. That has yet to be proved. But it is subject to criticism on at least two grounds. First, does it make sense to acquire everything without regard to the inherent worth of the material? Pargellis calls this the "grab-all method" and insists that we must be selective in our acquisition. ${ }^{5}$ On the other hand Metcalf says that we cannot perceive the future values of a given piece of printed matter, and so the only sensible approach is mass acquisition. ${ }^{6}$ Furthermore, he insists that if a library attempts to be selective in a great many fields it cannot be outstanding in any. ${ }^{7}$

Even stronger criticism is directed at the Farmington Plan on the grounds that library specialization on a national scale is a practical impossibility. Consider the overlapping in scientific fields such as biochemistry, physical chemistry, and astrophysics. Or, to take another example, suppose three libraries choose to specialize in segments of the field of history, e.g., British history, twentieth century history and German history. Which one should receive a history of World War I or II ? ${ }^{8}$ I represent one of two libraries which are currently trying specialization on a much broader scale and I know how serious this criticism is. Furthermore, where university and not public libraries are concerned, this specialization has strong implications for the curriculum. Farmington Plan supporters will reply that each institution is free to continue to buy in any field, but with as many

\footnotetext{
posal for a Division of Responsibility among American Libraries in the Acquisition and Recording of Library Materials." College and Research Libraries 5:105.09, March 1944.

s Pargellis, Stanley. "Building a Research Library." College and Research Libraries 5:110-14, March 1944. 6 Metcalf and Williams, op. cit.

7 Metcalf and Williams, Keyes D. "Dit. ing." College and Research Libraries 6:417-19, September 1945 .

8 Taube, Mortimer. "The Realities of Library Specialization." Library Quarterly 12:246-56, April 1942 and Rider, Fremont. The Scholar and the Future of the Research Library. ... New York, Hadham Press, I 944 , p. 71 .
} 
as 6000 journals in some scientific fields, is there not a danger that all but the best financed libraries will eventually specialize in one field to the detriment or exclusion of all others?

Although acquisitions under the Farmington Plan are world-wide in coverage, the Plan is national from the standpoint of division of responsibility and use of materials. In order that Farmington materials, which are distributed throughout the United States, may be nationally available, it follows that we must have a central location record. This is being provided by listing each item in the Union Catalog at the Library of Congress, which brings us to a consideration of the union catalog as the second significant means with which we have experimented and are experimenting to solve our problems. I am sure that you are familiar with individual examples of union catalogs such as those in the Pacific Northwest, Denver, Cleveland and Philadelphia, and that I need not describe individual regional catalogs in detail.

Almost without exception regional union catalogs are author catalogs designed for one of two purposes. First, the static purpose is to determine whether a given book is available within the region covered by the catalog. Under this heading our main objective is to locate material desired for interlibrary loan. Second, the union catalog may reveal that two or more libraries in geographical proximity are duplicating publications unnecessarily and neglecting to acquire equally significant publications in the same field. Let us call this the dynamic purpose of a union catalog because if action results from this knowledge, member libraries change in character, even though slightly.

Downs says that it is fair to state "that

' Carlson, William H. "The Research Worker and the Library." College and Research Libraries $7: 291$ 300 , October 1946. most union catalog sponsors have not been particularly concerned with fitting their catalogs into any kind of national plan, and, consequently, some duplication of effort, questionable regional division, and other lack of integration are evident." ${ }_{10}$ At the time Union Catalogs in the United States was published, it was recognized that there was a strong feeling that union catalogs were wasteful and not justified. ${ }^{11}$ This criticism may be said to be valid for several reasons. Existing regional union catalogs were created for the most part with W.P.A. funds, but even in prewar dollars they were expensive and, in terms of library income, are still reasonably expensive to maintain. Not enough attention has been given to this latter aspect of the problem, although the Pacific Northwest Library Association has developed what appears to be a successful formula for financing that region's union catalog through contributions of participating libraries. ${ }^{12}$ We have a substantial body of opinion to support the theory that a single national union catalog, properly completed, would make existing regional union catalogs unjustifiable in view of the services they can render over and above the Union Catalog, at the Library of Congress. It is hard to justify a regional union catalog as a location tool alone, except in special complicated situations such as Philadelphia, especially in view of modern means of communication and the establishment of air mail parcel post. Local union catalogs will be even harder to justify for location purposes if the national union catalog is expanded to show many locations for each entry. Can we then defend the regional union catalog as presently established on the dynamic basis

10 Downs, Robert B. "American Library Cooperation in Review." College and Research Libraries 6:408, September 1945 .

i1 Berthold, Arthur B. "Manual of Union Catalog Administration," in Downs, Robert B. ed. Union Catalogs in the United States. Chicago, A.L.A., 1942, p. 272 . Center." Library Journal 71:1121-23, Dec. 1 , 1945. 
alone, that we may thereby more intelligently distribute acquisitions? It seems to me that if the Farmington Plan in some form is a success, part of this argument is eliminated by virtue of agreed fields of specialization, and it appears further that unnecessary duplication can be eliminated by some less expensive means than the union catalog.

Union catalogs for the most part provide no subject approach to materials. Few of us will deny that we must have an improved subject approach to present resources. It follows with even greater emphasis that we must have an improved subject approach to vastly increased resources, but I have already stated that the adequacy and cost of cataloging are a grave concern to almost every research library. Therefore, should we not consider a substitute for the subject catalog before we proceed much further with our plans to increase our acquisitions?

Many a research library director is alarmed that more and more highly trained people work behind the scenes as catalogers while insufficiently trained or untrained people work with the public. ${ }^{13}$ It is much easier to see a room full of uncataloged books than it is to evaluate the harm done to your service by lowering the quality of people who wait on the public. This is a nonmonetary cost of cataloging. As an example of dollars and cents cost, Harvard has had a dozen or more catalogs since I 764 because one generation of catalogers has done over the work of its predecessor. ${ }^{14}$ No one has yet found a solution to the independent cataloging which we all do on the 30 to 40 per cent of the books for which we cannot buy L.C. Cards.

More serious than cost is the inadequacy of the card catalog as a subject tool. The head of a large research library writes me

13 Osborn, Andrew D. "The Crisis in Cataloging."

Library Quarterly $1 \mathrm{I}: 393-4 \mathrm{I}$, Ocotber 1941. that the ". . . card catalog is already too unwieldy for untrained readers to use, and by untrained readers I mean not only college students but graduate students and our general public as well. . . An advanced reader often finds our subject headings outmoded. This situation grows worse each year. We, and other libraries, are still using headings drawn up so to 20 years ago."

We are indebted to Raymond Swank for a penetrating analysis of the two common ways of preparing a subject approach to library materials. ${ }^{15}$ First is the traditional book-to-subject method where we put a book under a few established entries which remain relatively unchanged from year to year. The second is the subject-to-book method, or subject bibliography method, under which one picks a subject and tries to get all the related material thereon including related material from various fields. Under this latter method, subjects are current and dynamic, changing with requirements. The weakness of the first method is that no cataloger can foresee all the implications of any one book. Swank describes the card catalog as the "shotgun method" of making materials available, which method is based on the fallacious assumption that readers' problems are stereotyped and that a general purpose, universal subject tool will satisfy all needs. The scholar is not interested in one type of material, such as books, or merely the material in one library. $\mathrm{He}$ is interested in all types of materials germane to his subject irrespective of location. The subject catalog has had its day and the answer to our problem is subject bibliography created on a national or international scale. We have not begun to explore the problems of adequate subject bibliography.

15 Swank, Raymond C. "Cooperative Subject Bibliography." College and Research Libraries 6:419-22, September 1945 . 
There is no doubt that satisfactory machinery may take years to create. Now is none too soon to undertake concerted action along these lines.

If we concede the inadequacy of the subject catalog, and I think research librarians must concede it, we are still faced with the need for and cost of author catalogs for our collections. Much has been done to improve and simplify cataloging. The stumbling block to cooperative cataloging is the refusal of the central publishing agency to accept, unedited, the copy submitted by cooperating libraries. ${ }^{16}$ L.C. cards are still slow in appearing, cover at the maximum only 60 to 70 per cent of our books and still require processing in the local library. The people who have written me in regard to this subject are still not convinced that cataloging centralized in the Library of Congress is the answer to our problems. To what extent this attitude may be motivated by regionalism, I am not prepared to say, but regional organizations are contemplating the possibility of their own centralized cataloging.

One of our other unsolved problems is how to store the rising influx of acquisitions. We are justified in trying to solve the problem on the assumption that we shall continue to deal with the book in its traditional form plus reasonable amounts of microphotographic material. The microcard has been discussed so throughly that I wish to add just one thought with respect to it. The system proposes to eliminate the cataloging problem by wrapping book and cataloging into one package. In view of the deficiencies of the card catalog, does anyone believe that the limited subject approach proposed for microcards will be anything but less satisfactory than the present subject catalog?

The most constructive step to the solution of our space problem is the cooperative

10 Metcalf, "Division of Fields . . ," op cit. deposit library, not merely because it costs an estimated Io cents to store a book for one year in a deposit library vs. approximately $\$ 1.00$ in our conventional buildings, but because this idea has implications for regional and national planning. ${ }^{17}$ We have heard a great deal in regard to the experience of the New England Deposit Library which is located near the participating libraries. We look forward with interest to the possible founding of a deposit library on a more ambitious scale in the Middle West because it would represent wider geographical coverage and give us added evidence with respect to the feasibility of this type of undertaking.

Pending the accumulation of this evidence, however, we should consider the implications that the cooperative deposit library may have for our other problems. First, we must prove that it is practicable to locate a deposit library a few hundred miles from some of the cooperating libraries. If this be true, we have established an extremely important point. Second, only if we amalgamate deposit library books from all cooperating libraries and eliminate most duplication will we realize the full potentialities of the deposit idea. Such elimination of duplication is the only intelligent manner I can see to reduce our bookstocks, for it is generally conceded that weeding on any other basis is an impossibility. If we proceed on any basis other than merging of deposit library collections and elimination of duplicate copies, each library might as well build its own warehouse and forget the problem of geographical location.

\section{Conclusions}

If we are going to meet the deficiency of the subject approach to materials, we must turn to pure subject bibliography on a national scale. The job is too large for any one region. It requires national plan-

${ }^{17}$ Doherty, Francis X. "The New England Deposit Library." Library Quarterly 18:252-53, October 1948. 
ning and national financial support. If we are going to acquire huge amounts of materials, we are obligated to make them useful to the scholar wherever he may be. How can the individual library interpret this mass of materials except by subject bibliographies rather than through a single subject or classified catalog in Washington, D.C.? Farmington planning at one point recognized that it would be difficult to specialize and that both for this reason and for economy in handling material it would be preferable to put one copy of everything in a super-library, i.e. the Library of Congress. An alternative to the single super-library idea was considered in order to reduce the dangers of the atomic age and the disadvantages created by the great distances which separate so many areas from Washington. This alternative was to establish three super-libraries, each of which would house duplicate copies of Farmington materials. ${ }^{18}$ It is easy to understand why it was not possible to proceed at once on such an ideal basis, but that is the ultimate key to the satisfactory solution of many of our problems. In addition to serving as regional super-libraries, these institutions could become the deposit warehouses for libraries in their respective regions. By this means we could create strong collections of older materials in the two super-libraries outside the Library of Congress, and even its collections could thus be made more complete as checking of the Philadelphia Union Catalog has demonstrated. Backed by these regional collections, each research library could tailor its acquisitions and services to its special needs. It seems unrealistic to expect a university or even a public research library to do otherwise.

Just one warning. When President Roosevelt proposed the production of 50,000

18 Ellsworth, Ralph E. and Kilpatrick, Norman L. "Midwest Reaches for the Stars." College and Research Libraries 9:136-44, April 1948. aircraft per year at the beginning of World War II, many people, including industrialists, said it was impossible. No one thought to ask who would service and fly the airplanes, and the Air Forces were hampered by trained personnel shortages throughout much of World War II. Impossible through it may now seem, some national approach to our problems can and must come as surely as our manufacturers turned out 50,000 airplanes a year. Cooperation and plans are not enough. We must meet the need for much better trained reference librarians, catalogers and bibliographers. Let us stop paying lip service to the idea that we are educators unless we get the educator's training and point of view. Carman, ${ }^{19}$ McIntosh, Conant, ${ }^{20}$ Colwell, ${ }^{21}$ Hutchins $^{22}$ and people in our own profesfession, such as Beals ${ }^{23}$ and Gitler, ${ }^{24}$ have emphasized the need of a general education. Shall we continue to compromise by moving any part of library training into the undergraduate school, thereby diluting its curriculum? The cry of research libraries from one end of the country to the other is for subject specialists. We need people with a sound general education, plus subject specialization and proper library training. Reference librarians and catalogers as presently trained-and I say this with some knowledge of the changed curricula of our library schools-are not being equipped to meet today's needs and will surely not be equipped to deal with tomorrow's problems. We must produce cataloger-bibliographers with a scholar's appreciation of research,

\footnotetext{
19 Speech delivered at the Conference of Eastern College Librarians, Nov. 27, 1948, Columbia University. so Harvard University. Committee on the Objectives of a General Education in a Free Society. General Education in a Free Society. . . C Cambridge, Mass. The University, 1945. (See introduction)

${ }_{21}$ Colwell, Ernest C. "The Role of the Professional School in the University." Library Journal 73:134044 , Oct. 1,1948 .

2a Hutchins, Robert M. The Higher Learning in America. New Haven, Yale University Press, 1936. ${ }_{23}$ Beals, Ralph A. "Education for Librarianship." Library Quarterly 17:296 ff., October 1947.

24 Gitler, Robert L. "Today's Librarians Need Broad Education." Library Journal 73:359-63, Mar. 1, 1948.
} 
and reference librarians who know how to use the entire range of resources of great libraries, not merely 200 or 300 ready reference books. To command people of this quality, we must pay higher salaries. Those of us in the field owe it to our library schools to get the salaries which will justify the type of people we demand and need.

We must undertake integrated planning with respect to all our problems and critically examine both our methodology and our isolated experiments at solving our problems. What we need is a full scale planning organization composed of carefully selected research library directors with divergent points of view, not merely partisans who favor regionalism on the one hand or a completely national approach on the other. In addition, the planning organization should include expert catalogers, out- standing research librarians and subject bibliographers, the last group preferably from outside the profession. We should look to this organization to bring us an over-all plan which we will support both as it affects our libraries and as it has broader implications. We are going to need more than token federal financial assistance if we are to start a new era in librarianship. Our services and collections have proved indispensable to national defense and to education. Federal aid to libraries is every bit as important as federal aid to education. In fact, the one is incongruous without the other, and it is up to us to prove our case by concerted action and the assistance of those who need our services. Before this can be done, we need an intelligent plan with the wholehearted backing of our own profession.

\section{Joint Committee on Library Education of C.N.L.A.}

The second meeting of the Joint Committee on Library Education of the Council of $\mathrm{Na}$ tional Library Associations was held in New York on May 27. Among topics discussed were the following: the urgent need of a public list of library schools accredited by the A.L.A. Board of Education for Librarianship, the question of establishing standard examinations which could be substituted for professional training, the possibility of a thorough study of the backgrounds of training needed for special librarianship, and the development of informational services by the joint committee. Maurice F. Tauber represents the Association of College and Reference Libraries on this committee.

\section{I949-50 A.C.R L. Officers}

The following persons, elected by mail ballot, took office July I, 1949. A complete list of A.C.R.L. officers, including section officers, will appear in the October issue.

President: Wyllis E. Wright, librarian, Williams College, Williamstown, Mass.

Vice President and President-Elect:
Charles M. Adams, librarian, Woman's College Library, University of North Carolina, Greensboro.

Treasurer: Thomas S. Shaw, assistant in charge, Public Reference, Main Reading Room, Library of Congress, Washington, D.C. 